DiRECTEURS DE LA PUBLICATION / PUBLICATION DIRECTORS:

Bruno David, Président du Muséum national d'Histoire naturelle

Étienne Ghys, Secrétaire perpétuel de l'Académie des sciences

RÉDACTEURS EN CHEF / EDITORS-IN-CHIEF: Michel Laurin (CNRS), Philippe Taquet (Académie des sciences)

AssistANTE DE RÉDACTION / AssistANT EDITOR: Adenise Lopes (Académie des sciences; cr-palevol@academie-sciences.fr)

MISE EN PAGE / PAGE LAYOUt: Audrina Neveu (Muséum national d'Histoire naturelle; audrina.neveu@mnhn.fr)

RÉVISIONS LINGUISTIQUES DES TEXTES ANGLAIS / ENGLISH LANGUAGE REVISIONS: Kevin Padian (University of California at Berkeley)

RÉDACTEURS ASSOCIÉS / ASSOCIATE EDITORS ( ${ }^{*}$, took charge of the editorial process of the article/a pris en charge le suivi éditorial de l'article):

Micropaléontologie/Micropalaeontology

Maria Rose Petrizzo (Università di Milano, Milano)

Paléobotanique/Palaeobotany

Cyrille Prestianni (Royal Belgian Institute of Natural Sciences, Brussels)

Métazoaires/Metazoa

Annalisa Ferretti (Università di Modena e Reggio Emilia, Modena)

Paléoichthyologie/Palaeoichthyology

Philippe Janvier (Muséum national d'Histoire naturelle, Académie des sciences, Paris)

Amniotes du Mésozoïque/Mesozoic amniotes

Hans-Dieter Sues* (Smithsonian National Museum of Natural History, Washington)

Tortues/Turtles

Juliana Sterli (CONICET, Museo Paleontológico Egidio Feruglio, Trelew)

Lépidosauromorphes/Lepidosauromorphs

Hussam Zaher (Universidade de São Paulo)

Oiseaux/Birds

Eric Buffetaut (CNRS, École Normale Supérieure, Paris)

Paléomammalogie (mammifères de moyenne et grande taille)/Palaeomammalogy (large and mid-sized mammals)

Lorenzo Rook (Università degli Studi di Firenze, Firenze)

Paléomammalogie (petits mammifères sauf Euarchontoglires)/Palaeomammalogy (small mammals except for Euarchontoglires)

Robert Asher (Cambridge University, Cambridge)

Paléomammalogie (Euarchontoglires)/Palaeomammalogy (Euarchontoglires)

K. Christopher Beard (University of Kansas, Lawrence)

Paléoanthropologie/Palaeoanthropology

Roberto Macchiarelli (Université de Poitiers, Poitiers)

Archéologie préhistorique/Prehistoric archaeology

Marcel Otte (Université de Liège, Liège)

RÉFÉRÉS / REVIEWERS: https://sciencepress.mnhn.fr/fr/periodiques/comptes-rendus-palevol/referes-du-journal

COUVERTURE / COVER:

Excavation at Ao Kalang site, Kut Island, Thailand (Credits: Eric Buffetaut).

Comptes Rendus Palevol est indexé dans / Comptes Rendus Palevol is indexed by:

- Cambridge Scientific Abstracts

- Current Contents ${ }^{\circledR}$ Physical

- Chemical, and Earth Sciences ${ }^{\circledR}$

- ISI Alerting Services ${ }^{\circledR}$

- Geoabstracts, Geobase, Georef, Inspec, Pascal

- Science Citation Index ${ }^{\circledR}$, Science Citation Index Expanded ${ }^{\circledR}$

- Scopus ${ }^{\circledR}$.

Les articles ainsi que les nouveautés nomenclaturales publiés dans Comptes Rendus Palevol sont référencés par / Articles and nomenclatural novelties published in Comptes Rendus Palevol are registered on:

- ZooBank ${ }^{\circledR}$ (http://zoobank.org)

Comptes Rendus Palevol est une revue en flux continu publiée par les Publications scientifiques du Muséum, Paris et l'Académie des sciences, Paris Comptes Rendus Palevol is a fast track journal published by the Museum Science Press, Paris and the Académie des sciences, Paris

Les Publications scientifiques du Muséum publient aussi / The Museum Science Press also publish:

Adansonia, Geodiversitas, Zoosystema, Anthropozoologica, European Journal of Taxonomy, Naturae, Cryptogamie sous-sections Algologie, Bryologie, Mycologie.

L'Académie des sciences publie aussi / The Académie des sciences also publishes:

Comptes Rendus Mathématique, Comptes Rendus Physique, Comptes Rendus Mécanique, Comptes Rendus Chimie, Comptes Rendus Géoscience, Comptes Rendus Biologies.

Diffusion - Publications scientifiques Muséum national d'Histoire naturelle

CP 41 - 57 rue Cuvier F-75231 Paris cedex 05 (France)

Tél. : 33 (0)1 40794805 / Fax: 33 (0)1 40793840

diff.pub@mnhn.fr / https://sciencepress.mnhn.f

Académie des sciences, Institut de France, 23 quai de Conti, 75006 Paris.

(C) Publications scientifiques du Muséum national d'Histoire naturelle / @ Académie des sciences, Paris, 2021

ISSN (imprimé / print): 1631-0683/ ISSN (électronique / electronic): 1777-571X 


\title{
Turtle remains from the Early Cretaceous of Kut Island, Gulf of Thailand
}

\author{
Haiyan TONG \\ Palaeontological Research and Education Centre, Mahasarakham University, \\ Khamrieng Sub-district, Kantharawichai District, Maha Sarakham Province 44150 (Thailand) \\ and Key Laboratory of Vertebrate Evolution and Human Origins, Institute of Vertebrate \\ Paleontology and Paleoanthropology, Chinese Academy of Science, Beijing 100044 (China) \\ htong09@yahoo.fr (corresponding author)
}

Wilailuck NAKSRI

Northeastern Research Institute of Petrified Wood and Mineral Resources, Nakhon Ratchasima Rajabhat University, Mueang Nakhon Ratchasima 30000 (Thailand)

Eric BUFFETAUT

Palaeontological Research and Education Centre, Mahasarakham University, Khamrieng Sub-district, Kantharawichai District, Maha Sarakham Province 44150 (Thailand) and CNRS, UMR 8538, Laboratoire de géologie de l'École normale supérieure,

PSL Research University, 23 rue Lhomond, 75231 Paris cedex 05 (France)

\section{Suravech SUTEETHORN Varavudh SUTEETHORN \\ Uthumporn DEESRI}

Palaeontological Research and Education Centre, Mahasarakham University, Khamrieng Sub-district, Kantharawichai District, Maha Sarakham Province 44150 (Thailand) and Department of Biology, Faculty of Science, Mahasarakham University, Kantarawichai, Maha Sarakham 44150 (Thailand)

\begin{abstract}
Julien CLAUDE
Institut des Sciences de l'Évolution de Montpellier, CNRS/UM/IRD/EPHE, 2 place Eugène Bataillon, cc64, 34095 Montpellier cedex 5 (France)
\end{abstract}

Submitted on 7 February 2020 | Accepted on 11 May 2020 | Published on 3 May 2021 


\author{
KEY WORDS
Testudines, \\ Trionychoidae, \\ Early Cretaceous, \\ Kut Island \\ Thailand.
}
MOTS CLÉS
Testudines,
Trionychoidae,
Crétacé inférieur,
île de Kut,
Thaillande.

\section{ABSTRACT}

An isolated first costal turtle plate from the Early Cretaceous of Kut Island, Gulf of Thailand, is reported and assigned to Trionychoidae gen. et sp. indet. The morphology of the plate and comparison with turtle assemblages of the Khorat Group support the correlation of the vertebratesbearing beds of Kut Island with the Sao Khua Formation, as already suggested by the studies on sharks and dinosaurs.

\section{RÉSUMÉ}

Restes de tortue du Crétacé inférieur de lîle de Kut, Golfe de Thaïlande.

Une plaque de tortue isolée (costale 1), provenant du Crétacé inférieur de l'île de Kut, dans le Golfe de Thaillande, est décrite et attribuée à Trionychoidae gen. et sp. indet. La morphologie de la plaque et la comparaison avec les assemblages de tortues du Groupe Khorat soutiennent la corrélation des couches à vertebrés de l'île de Kut avec la formation Sao Khua, comme cela a déjà été suggéré par les études sur les requins et dinosaures.

\section{INTRODUCTION}

Kut Island (Ko Kut in Thai, Trat Province) is a junglecovered island situated in the eastern part of the Gulf of Thailand, close to the Cambodian border (Fig. 1). Mesozoic vertebrates from Kut Island were discovered in the 1970s and first reported by Buffetaut $\&$ Ingavat in 1983 (Buffetaut \& Ingavat 1983). Since the 1980s, successive visits by the Department of Mineral Resources, and Palaeontological Research and Education Centre (Mahasarakham University, Thailand), in collaboration with palaeontologists from France and Denmark, have allowed numerous vertebrate fossils to be collected. According to the recent studies (Cuny et al. 2010; Buffetaut et al. 2019), the vertebrate fauna from Kut Island consists of hybodont sharks (Hybodus sp., Isanodus paladeji Cuny, Suteethorn, Kamha, Buffetaut \& Philippe, 2006, and Heteroptychodus kokutensis Cuny, Laojumpon, Cheychiw \& Lauprasert, 2010), actinopterygians (Semionotiformes indet., Lepidodes sp.), turtles, crocodilians (goniopholidid and cf. Theriosuchus sp.), and theropod (including spinosaurids) and sauropod dinosaurs. This assemblage is indicative of a freshwater environment and is considered as Early Cretaceous in age, coeval to the Sao Khua Formation of the Khorat Group.

Vertebrate fossils have been collected from the grey sandstone outcrops on the shore of the island, just above the sea level in two localities on the Kut island, apparently coeval with one another, Ao Phak on the northwestern coast, and Ao Kalang on the southeastern coast. Most fossils come from the Ao Kalang locality, south of Ao Kalang Village (Ban Ao Kalang in Thai). For more geological information, see Cuny et al. (2010). Turtle remains from Kut Island are in general very fragmentary. In this paper we report on a nearly complete costal 1 plate from Ao Kalang site. The specimen is housed in the Palaeontological Research and Education Centre (PRC), Mahasarakham University, Thailand. Its stratigraphic significance is discussed.

\section{SYSTEMATIC PALAEONTOLOGY}

\author{
Order TESTUDINES Linnaeus, 1758 \\ Sub-order CRYPTODIRA Cope, 1868 \\ Superfamily TRIONYCHOIDAE \\ (sensu Gaffney \& Meylan 1988)
}

Trionychoidae gen. et sp. indet.

(Fig. 2)

\section{DESCRIPTION}

The specimen (PRC149) is an almost complete first right costal plate, lacking only the lateral tip and part of the medial margin, which is damaged (Fig. 2). The plate is roughly triangular and slightly convex dorsally. As preserved, it measures $110 \mathrm{~mm}$ in length, $160 \mathrm{~mm}$ in width and $8 \mathrm{~mm}$ in thickness. The outer surface is covered with clear ornament of pitted pattern, formed by a network of irregular ridges. In the anterior marginal area, the ridges tend to arrange in a parallel manner, perpendicular to the border of the plate. Although wider than long, the plate is relatively long with the length/ width radio about $65 \%$. The sutural margin with the nuchal is partly preserved and those with the peripheral 1 and 2 are intact. The nuchal/costal 1 suture is oblique. The costal $1 /$ peripheral 1 suture and that of costal 1/peripheral 2 have the similar length. The contact with the peripheral 3 is not preserved, and it is not clear whether the costal 1/peripheral 4 contact is present because the relevant part of the plate is broken. Part of the medial margin of the plate is damaged, but the preserved sutural margin indicates that the neural 1 is apparently rectangular. The posterior border of the plate is slightly convex posteriorly.

The scute sulci, although thin, are clearly imprinted on the dorsal surface. The lateral sulcus of the vertebral 1 is divergent anteriorly, reaching about the mid-length of the peripheral 1; this indicates a trapezoidal shape for the vertebral 1 with the posterior margin shorter than the anterior one. The intervertebral sulcus between the vertebrals 1 and 2 is convex forward. The vertebral 2 is clearly narrower than the vertebral 1 . 
On the inner surface, the strong second thoracic rib is straight, with a stubby and rounded rib head and sharp anterior edge which extends through the whole width of the plate. The first thoracic rib is damaged, it is short.

\section{COMPARISON AND DISCUSSION}

Three major groups of turtles are known from the Late Jurassic to the Early Cretaceous in Asia: Xinjiangchelyidae, Macrobaenidae/Sinemydidae, and Trionychoidae (Sukhanov 2000; Danilov et al. 2017; Tong 2017). Trionychoidae are notable for presenting a sculptured shell surface, a feature allowing isolated plates to be identified (Danilov et al. 2011, 2013b; Tong et al. 2014; Vitek \& Joyce 2015; Georgalis \& Joyce 2017). The ornamentation in PRC149 which consists of a network of raised irregular ridges forming a pitted pattern is typical of Trionychoidae (sensu Gaffney \& Meylan 1988); such a sculpture is absent in Xinjiangchelyidae and Macrobaenidae/ Sinemydidae. Within Trionychoidae, the sculpture in PRC149 is reminiscent of some basal members of the group such as Isanemys srisuki Tong, Buffetaut \& Suteethorn, 2006 from the Lower Cretaceous Sao Khua Formation of NE Thailand and Ferganemys spp. from the mid-Cretaceous of Kyrgyzstan and Uzbekistan (Tong et al. 2006; Syromyatnikova 2011).

Among Trionychoidae, the presence of the scute sulci on the carapace surface and the contact with the peripherals exclude PRC149 from the Trionychidae and Carettochelyidae, and place it in a more basal position. The triangular shape of the costal 1 is similar to that of Adocidae such as Ferganemys spp., Isanemys srisuki, Protoshachemys rubra Tong, Buffetaut, Suteethorn, Suteethorn, Cuny, Cavin, Deesri, Martin, Wongko, Naksri \& Claude, 2019, Adocus spp. (Tong et al. 2006, 2009b, 2019a, b; Syromyatnikova \& Danilov 2009; Syromyatnikova 2011; Danilov et al. 2013b; Syromyatnikova et al. 2013), whereas in more primitive turtles such as the xinjiangchelyids Chengyuchelys spp., Xinjiangchelys spp., and Annemys spp., the costal 1 is shorter, with nearly parallel anterior and posterior borders (Ye 1986; Peng \& Brinkman 1993; Tong et al. 2012, 2015a; Rabi et al. 2014). It is noteworthy that some basal trionychoids, such as Siamochelys peninsularis Tong, Buffetaut \& Suteethorn, 2002 from the Jurassic of southern Thailand, Basilochelys macrobios Tong, Claude, Naksri, Suteethorn, Buffetaut, Khansubha, Wongko \& Yuangdetkla, 2009 from the Phu Kradung Formation (Khorat Plateau) and Sinaspideretes wimani Young \& Chow, 1953 from the Xiashaximiao Formation of the Sichuan Basin, China, have a short costal 1 similar to that of xinjiangchelyids (Tong et al. 2002, 2009a, 2014). This difference from more primitive turtles is also indicated by the costal 1 length/width radio in PRC149 (65\%) which is greater than that of xinjiangchelyids and macrobaenids (around 40\% to 50\%) and falls within the range of primitive Adocidae (Isanemys srisuki (61\%) and Ferganemys verzilini Nessov \& Khosatzky, 1977 (64\%) (Tong et al. 2009b; Syromyatnikova 2011), whereas Siamochelys peninsularis (44\%) and Basilochelys macrobios (38\%) have a costal 1 length/width radio similar to that of xinjiangchelyids

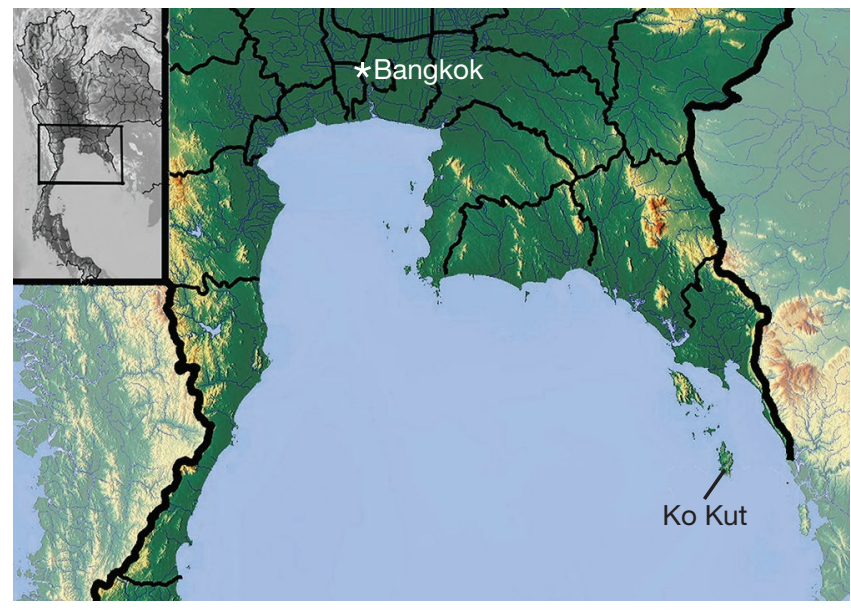

FIG. 1. - Location map showing the position of Kut Island in the Gulf of Thailand (after Buffetaut et al. 2019).

(Tong et al. 2002, 2009a). The relatively high costal 1 length/ width value in S. wimani (54\%) is likely related to the narrow anterior part of the shell, the morphology of this plate with the parallel anterior and posterior margins is closer to the condition in xiniangchelyids than to trionychoids (Tong et al. 2014). Among Trionychoidae, nanhsiungchelyids also have a relatively long costal 1 and many of them reach a large size, but the ornamentation of the shell surface is more prominent than that of PRC149 (Hirayama et al. 2001; Danilov et al. 2013a; Brinkman et al. 2015).

The non-marine Mesozoic deposits of Thailand are rich in basal trionychoid fossils. Several taxa have been reported from the Khorat Group (Late Jurassic - Early Cretaceous). These include the large Basilochelys macrobios from the upper part of the Phu Kradung Formation, the small Isanemys srisuki and Protoshachemys rubra from the Sao Khua Formation, and the medium-sized Shachemys sp. from the Khok Kruat Formation (Tong et al. 2005, 2006, 2009a, 2019a). Large trionychoid turtle remains have also been collected from the Sao Khua Formation and stratigraphically coeval beds in eastern Thailand, but they are too fragmentary to warrant precise systematic assignment. As mentioned above, on the basis of the shape and the length/width radio of the costal 1, PRC149 is more derived than Basilochelys. In addition, the vertebral 1 in PRC149 is trapezoidal in shape and wider than the vertebral 2, whereas in $B$. macrobios, the vertebral 1 is roughly as wide as the vertebral 2, with the lateral borders slightly convergent forward (Tong et al. 2009a, b). With a carapace length estimated as about $75 \mathrm{~cm}$, PRC149 may be close to a large trionychoid turtle yet to be named from the Sao Khua Formation.

\section{AGE OF THE KUT ISLAND DEPOSITS}

When Buffetaut \& Ingavat (1983) first reported vertebrate remains from Kut Island, they tentatively assigned the assemblage an Early Jurassic age, which was in accordance with the attribution of the fossil-bearing strata to the Phu Kradung Formation (at the time referred to the Lower Jurassic (Tansathien 
A

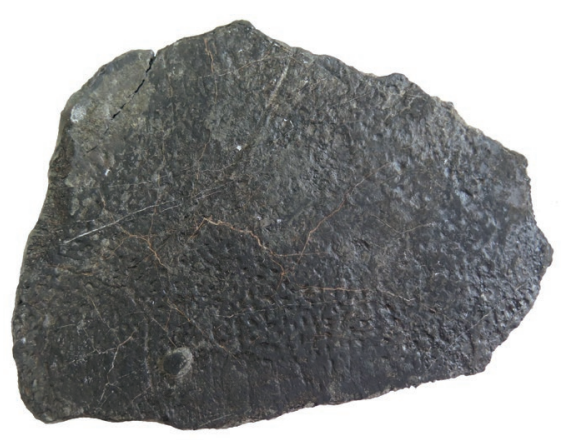

B

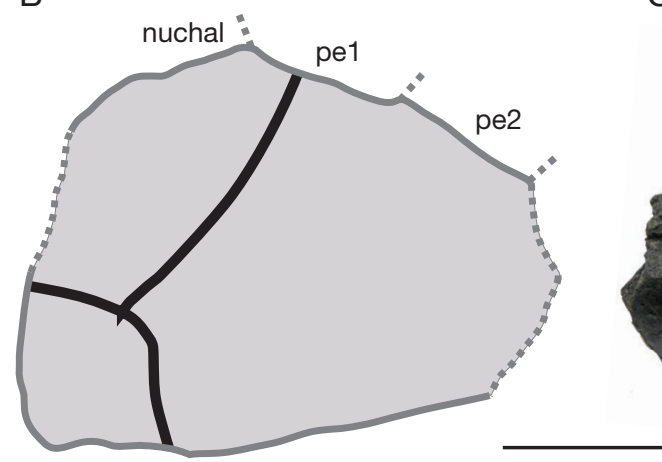

C

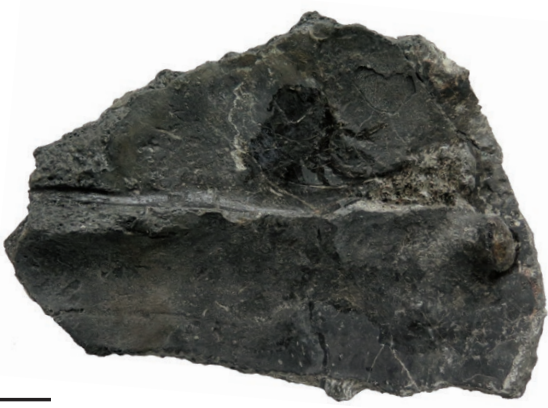

FIG. 2. - Trionychoidae gen. et sp. indet. (Testudines: Cryptodira) from the Early Cretaceous of Kut Island, Gulf of Thailand. Right costal 1 (PRC149) in dorsal (A, B) and ventral (C) views. The solid grey line indicates the sutural margin, the dotted grey line indicates the damaged margin and suture position of peripherals (pe) and nuchal plates; the black thick line represents the scute sulci. Scale bar: $5 \mathrm{~cm}$.

et al. 1979)). Based on the vertebrate fauna, notably shark assemblage, Cuny et al. (2010) correlated the vertebratebearing beds of Kut Island with the Sao Khua Formation of the Khorat Group. This conclusion is supported by the more recent study of spinosaurid dinosaur teeth (Buffetaut et al. 2019). The presence of a large trionychoid turtle provides further evidence about the stratigraphical correlation of Kut Island deposits. In the Khorat Group, the Phu Kradung Formation contains two distinct turtle assemblages. The assemblage from the lower part of the formation (Late Jurassic) consists of xinjiangchelyids (Phunoichelys thirakhupti Tong, Naksri, Buffetaut, Suteethorn, Suteethorn, Deesri, Sila, Chanthasit \& Claude, 2015 and Kalasinemys prasarttongosothi Tong, Naksri, Buffetaut, Suteethorn, Suteethorn, Chanthasit \& Claude, 2015). The upper part of the formation, which has yielded the abundant large basal trionychoid Basilochelys macrobios and an yet undescribed macrobaenid, is likely Early Cretaceous in age (Tong et al. 2009a, b, 2018). Turtle assemblages from the Sao Khua (Barremian) and Khok Kruat (Aptian-Albian) formations are so far exclusively composed of Trionychoidae. Adocidae and Carettochelyidae are recorded from both formations (the adocids Isanemys srisuki and Protoshachemys rubra, the carettochelyid Kyzilkumemys sp., and a large undetermined trionychoid from the Sao Khua Formation; and the adocid Shachemys sp. and the carettochelyid Kyzilkumemys khoratensis Tong, Suteethorn, Claude, Buffetaut \& Jintasakul, 2005 from the Khok Kruat Formation (Tong et al. 2005, 2006, 2009b). Large trionychoid turtle remains have also been recorded from the Pra Prong locality (Sa Kaeo Province, eastern Thailand) which is coeval with the Sao Khua Formation; but they are (so far) not recorded from the Khok Kruat Formation. As mentioned above, the costal 1 from Kut Island is excluded from Trionychidae and Carettochelyidae; and its morphology is more derived than that of Basilochelys macrobios from the Phu Kradung Formation. Our study of the turtle remains would therefore support the conclusions based on sharks and dinosaurs (Cuny et al. 2010; Buffetaut et al. 2019), viz. that the vertebrate-bearing beds of Kut Island are Early Cretaceous rather than Jurassic in age and can be correlated with the Sao Khua Formation of the Khorat Group.

\section{CONCLUSION}

The first costal plate (PRC149) from Kut Island is assigned to Trionychoidae gen. et sp. indet. It represents a large primitive trionychoid turtle that is more derived than Basilochelys macrobios from the Phu Kradung Formation. By the comparison with turtle faunas from the Mesozoic of South East Asia, our study supports the correlation of the vertebrate-bearing beds of Kut Island with the Sao Khua formation of the Khorat Group, as do the studies on sharks and dinosaurs.

\section{Acknowledgements}

We thank all members of the Palaeontological Research and Education Centre (PRC), Mahasarakham University and the Department of Mineral Resources (DMR) who took part the field work at Kut Island. This research project is financially supported by Mahasarakham University (Fast Track 2020 and the Mahasarakham University Development Fund), the National Research Council of Thailand (NRCT) of the fiscal years 2018 and 2019, and the International Research GroupPalBioDivASE (GDRI) grant of CNRS.

\section{REFERENCES}

Brinkman D. B., Tong H., Li H., Sun Y., Zhang J.-S., GodeFROIT P. \& ZHANG Z.-M. 2015. - New exceptionally wellpreserved specimens of "Zangerlia" neimongolensis from Bayan Mandahu, Inner Mongolia, and their taxonomic significance. Comptes Rendus Palevol 14 (6): 577-587. https://doi.org/10.1016/j. crpv.2014.12.005

Buffetaut E. \& Ingavat R. 1983. - Vertebrates from the continental Jurassic of Thailand. CCOP Technical Bulletin 16: 68-75.

Buffetaut E., Suteethorn S., Suteethorn V., Tong H. \& WongKo K. 2019. - Spinosaurid teeth from the Lower Cretaceous of Ko Kut, eastern Thailand. Annales de Paléontologie 105: 239-243. https://doi.org/10.1016/j.annpal.2019.03.006

CUNY G., LAOJUMPON C. \& LAUPRASERT K. 2010. - Fossil vertebrate remains from Kut Island (Gulf of Thailand, Early Cretaceous). Cretaceous Research 31 (4): 415-423. https://doi.org/10.1016/j. cretres.2010.05.007 
Danilov I. G., SukHanov V. B. \& Syromyatnikova E. V. 2011. New Asiatic materials on turtles of the family Adocidae with a review of the adocid record in Asia. Proceedings of the Zoological Institute RAS 315 (2): 101-132.

Danilov I. G., Sukhanov V. B. \& Syromyatnikova E. V. 2013a. - A redescription of Zangerlia dzamynchondi (Testudines: Nanhsiungchelyidae) from the Late Cretaceous of Mongolia with a reassessment of the phylogenetic position and relationships of Zangerlia, Morphology and Evolution of Turtles. Springer, Dordrecht: 407-417.

Danilov I. G., Syromyatnikova E. V., SkUtschas P. P., Kodrul T. M. \& Jin J. 2013b. - The first 'true'Adocus (Testudines, Adocidae) from the Paleogene of Asia. Journal of Vertebrate Paleontology 33 (5): 10711080. https://doi.org/10.1080/02724634.2013.768254

Danilov I. G., Syromyatnikova E. V. \& SuKHANOV V. B. 2017. Subclass Testudinata, in Lopatin A. V. \& Zelenkov N. V. (eds), Fossil vertebrates of Russia and adjacent countries. Fossil Reptiles and Birds. Part 4. GEOS, Moscow: 27-395.

GafFney E. S. \& MeYlan P. A. 1988. - A phylogeny of turtles, in BENTON M. J. (ed.), The Phylogeny and Classification of the Tetrapods, Vol. 1, Amphibians, Reptiles, Birds. Oxford, Clarendon Press: 157-219.

Georgalis G. L. \& Joyce W. G. 2017. - A review of the fossi record of Old World turtles of the clade Pan-Trionychidae. Bulletin of the Peabody Museum of Natural History 58 (1): 115-208. https://doi.org/10.3374/014.058.0106

Hirayama R., Sakurai K., Chitoku T., KaWakami G. \& Kito N. 2001. - Anomalochelys angulata, an unusual land turtle of family Nanhsiungchelyidae (superfamily Trionychoidea; order Testudines) from the Upper Cretaceous of Hokkaido, North Japan. Russian Journal of Herpetology 8 (2): 127-138.

Peng J.-H. \& Brinkman D. B. 1993. - New material of Xinjiangchelys (Reptilia: Testudines) from the Late Jurassic Qigu Formation (Shishugou Group) of the Pingfengshan locality, Junggar Basin, Xinjiang. Canadian Journal of Earth Sciences 30 (10): 2013-2026. https://doi.org/10.1139/e93-177

Rabi M., Sukhanov V. B., Egorova V. N., Danilov I. \& Joyce W. G. 2014. - Osteology, relationships, and ecology of Annemys (Testudines, Eucryptodira) from the Late Jurassic of Shar Teg, Mongolia, and phylogenetic definitions for Xinjiangchelyidae, Sinemydidae, and Macrobaenidae. Journal of Vertebrate Paleontology 34 (2): 327 352. https://doi.org/10.1080/02724634.2013.807274

SuKHANOV V. B. 2000. - Mesozoic turtles of middle and central Asia, in Benton M. J., Shishrin M. A., Unwin D. M. \& KUROCHKIN E. N. (eds), The age of dinosaurs in Russia and Mongolia Cambridge University Press, Cambridge: 309-367.

SyromyatniKOVa E. V. 2011. - Turtles of the genus Ferganemys Nessov et Khosatzky, 1977 (Adocidae): shell morphology and phylogenetic position. Proceedings of the Zoological Institute of the Russian Academy of Sciences 315 (1): 38-52.

Syromyatnikova E. V. \& Danilov I. G. 2009. — New material and a revision of turtles of the genus Adocus (Adocidae) from the Late Cretaceous of Middle Asia and Kazakhstan. Proceedings of the Zoological Institute RAS 313 (1): 74-94.

Syromyatnikova E. V., Danilov I. G. \& SukHanov V. B. 2013.The skeletal morphology and phylogenetic position of Adocus amtgai, an adocid turtle from the Late Cretaceous of Mongolia. Cretaceous Research 45: 155-173. https://doi.org/10.1016/j. cretres.2013.07.006

Tansathien W., Polprasit C. \& Pajilprapaporn V. 1979. Krong Khemarak Phoumin 1: 250,000 Geological Map of Thailand. Geological Survey Division, Department of Mineral Resources, Bangkok.

Tong H. 2017. - Testudines, in LI J. \& Tong H., Parareptilians, Captorhines and Testudines, Palaeovertebrata Sinica, Vol. II, Amphibians, Reptiles and Avians, Fasc. 2. Science Press, Beijing: 92-365.

Tong H., Buffetaut E. \& Suteethorn V. 2002. - Middle Jurassic turtles from southern Thailand. Geological Magazine 139 (6): 687-697. https://doi.org/10.1017/S0016756802006805
Tong H., Suteethorn V., Claude J., Buffetaut E. \& JinTASAKUL P. 2005. - The turtle fauna from the Khok Kruat Formation (Early Cretaceous) of Thailand. Proceedings of the International Conference on Geology, Geotechnology and Mineral Resources of Indochina (GEOINDO 2005), Khon Kaen: 610-614.

Tong H., Buffetaut E. \& Suteethorn V. 2006. — Isanemys, a new adocid turtle from the Sao Khua Formation (Early Cretaceous) of the Khorat Plateau, northeastern Thailand. Fossil Turtle Research 1: 128-137.

Tong H., Claude J., Naksri W., Suteethorn V., Buffetaut E., KhansubHa S., WongKo K. \& YuangdetKla P. 2009a. Basilochelys macrobios n. gen. and n. sp., a large cryptodiran turtle from the Phu Kradung Formation (latest Jurassic-earliest Cretaceous) of the Khorat Plateau, NE Thailand. Geological Society, London, Special Publications 315 (1): 153-173. https:// doi.org/10.1144/SP315.12

Tong H., Claude J., Suteethorn V., NaksRi W. \& Buffetaut E. 2009b. - Turtle assemblages of the Khorat Group (Late JurassicEarly Cretaceous) of NE Thailand and their palaeobiogeographical significance. Geological Society, London, Special Publications 315 (1): 141-152. https://doi.org/10.1144/SP315.11

Tong H., Danilov I., Ye Y., Ouyang H., Peng G. \& Li K. 2012. - A revision of xinjiangchelyid turtles from the Late Jurassic of Sichuan Basin, China. Annales de Paléontologie 98: 73-114. https://doi.org/10.1016/j.annpal.2012.01.001

Tong H., LI L. \& OuYANG H. 2014. - A revision of Sinaspideretes wimani Young \& Chow, 1953 (Testudines: Cryptodira: Trionychoidae) from the Jurassic of the Sichuan Basin, China. Geological Magazine 151 (4): 600-610. https://doi.org/10.1017/ S0016756813000575

Tong H., Dong Z. \& Wang T. 2015a. - A revision of Xinjiangchelys oshanensis (Ye, 1973), and new material from the Middle Jurassic of Lufeng, Yunnan Province, China. Bulletin de la Société géologique de France 186 (1): 43-49. https://doi. org/10.2113/gssgfbull.186.1.43

Tong H., Naksri W., Buffetaut E., Suteethorn V., Suteethorn S., Deesri U., Sila S., Chanthasit P. \& Claude J. 2015b. - A new primitive eucryptodiran turtle from the Upper Jurassic Phu Kradung Formation of the Khorat Plateau, NE Thailand. Geological Magazine 152 (1): 166-175. https://doi. org/10.1017/S0016756814000223

Tong H., Claude J., NaKsri W., Suteethorn V., Suteethorn S., Chanthasit P. \& Buffetaut E. 2018. - The age of the Phu Kradung Formation (Khorat Group, NE Thailand): Indications from the turtle faunas. JK2018, Geneva: 69-70.

Tong H., Buffetaut E., Suteethorn V., Suteethorn S., Cuny G., Cavin L., Deesri U., Martin J. E., Wongko K., NAKSRI W. \& Claude J. 2019a. - Phu Din Daeng, a new Early Cretaceous vertebrate locality on the Khorat Plateau, NE Thailand. Annales de Paléontologie 103 (3): 223-237. https://doi. org/10.1016/j.annpal.2019.04.004

Tong H., NaksRi W., Buffetaut E., Suteethorn S., Suteethorn V., Chantasit P. \& Claude J. 2019b. — Kalasine$m y s$, a new xinjiangchelyid turtle from the Late Jurassic of NE Thailand. Geological Magazine 147 (10): 1645-1656. https:// doi.org/10.1017/S0016756818000791

ViteK N. S. \& Joyce W. G. 2015. - A review of the fossil record of New World turtles of the clade Pan-Trionychidae. Bulletin of the Peabody Museum of Natural History 56 (2): 185-244. https:// doi.org/10.3374/014.056.0204

Ye X.-K. 1986. - A Jurassic turtle from Junggar, Xinjiang. Vertebrata PalAsiatica 24 (3): 171-181.

Submitted on 7 February 2020; accepted on 11 May 2020; published on 3 May 2021. 